\title{
Reality TV's Embrace of the Intern
}

\author{
Tanner Mirrlees
}

\author{
University of Ontario Institute of Technology, Oshawa, Canada, tanner.mirrlees@uoit.ca
}

\begin{abstract}
In the preface to a seminal exposé of the "intern nation," Ross Perlin (2012) writes, "reality TV truly embraces the intern" (xii). This article describes and analyzes how 20 reality TV intern job ads for 19 different reality TV studios represent the work of interns and internships in the capitalist reality TV industry. By interrogating how the job postings depict the work that reality TV studios expect interns to do, the skills that TV studios expect interns to possess as a prerequisite to considering them eligible for mostly unpaid positions, the asymmetrical power relations between studios and interns, and the studios' utilization of "hope" for a career-relevant experience to recruit interns, the article argues that the reality TV intern is actually a misclassified worker. The study demonstrates that reality TV interns are workers whose labour feeds reality TV production and that reality TV internships are a means of getting workers to labour without pay. The conclusion establishes some grounds for a reality TV intern class action suit.
\end{abstract}

Keywords: internships, cultural labour, reality TV, capitalism

In the preface to his seminal exposé of the proliferation of unpaid internships in the US, Ross Perlin (2012, xii) scrutinizes reality TV's glorification of unpaid internships in the cultural industries when he writes, "reality TV truly embraces the intern." Indeed, reality TV shows like The Hills, The Cut, and I Want to Work for Diddy represent workers doing jobs not for pay but for enriching experiences that will later help them land cultural industry careers. Reality TV studios also embrace the intern at the point of TV commodity production. A February 5, 2015 search for "reality TV internship" on US cultural industry job websites such as internships.com, simplyhired.com, and entertainment careers.net, for example, returned hundreds of ads for internship positions at US-based reality TV studios for spring and summer 2015. I have selected and analyzed 20 of these ads for internships at 19 different reality TV studios to understand how these ads represent the work of interns and internships in the capitalist reality TV industry. In this article, I interrogate how the job postings depict the work that reality TV studios expect interns to do, the skills that TV studios expect interns to possess as a prerequisite to landing mostly unpaid positions, the asymmetrical power relations between studios and interns, and the studios' utilization of "hope" for a career-relevant experience to recruit interns. I argue that the reality TV intern is actually a misclassified worker. My study demonstrates that reality TV interns are workers whose labour power feeds reality TV production and profits, and that reality TV internships are a means of getting workers to labour without pay.

To conduct this study, I closely analyzed 20 reality TV intern job postings, reading them to understand how they represent the intern's roles and tasks in the studios, the skills people are expected to possess as a prerequisite for getting hired as interns, the characteristics of internships, and the career-relevant "experience" that people supposedly get by doing them. Appendix A: Reality TV Job Search includes four tables that heuristically organize my findings. After collecting this data, I interpreted it by drawing on literature on the political economy of labour in the cultural industries (Brophy 2013; Cohen 2008, 2012; Deuze 2007; de Peuter 2014; Fuchs 2014; Huws 2007, 2010; Mosco and McKercher 2008; Mosco 2009; Ross 2004, 2009, 2013; Scholz 2013). Apropos the political economy of communication's dialectical movement between the empirical observation of capitalism and critical theorizing about it (Mosco 2009), I extrapolate from the reality TV internship job search findings to develop a Marxist critique of the 
capitalist reality TV industry's exploitation of workers via internships. By doing so, this article aims to complement and contribute to critical research on unwaged work in the cultural industries (Cohen 2008, 2012; Fuchs 2014; Scholz 2012), the reality TV industry's precarious low-to-no waged workforce (Andrejevic 2004, 2011; Blair 2010; Cianci 2009; Collins 2008; Hearn 2008, 2010, 2014; Mayer 2011; Oullette and Hay 2008; Raphael 1997; Ross 2014), and internships (de Peuter, Cohen and Brophy 2012; Perlin 2012).

Reality TV internship job postings are important to analyze because they offer an empirical snapshot of the substance of some reality TV internships at the present time. The ads do not paint a comprehensive picture of reality TV industry internships or constitute an ethnographic portrait of the lived labour experiences of the many people who do them. Rather, they provide insight into how reality TV companies rely on internships when producing reality TV shows, the types of jobs companies want interns to do, the skills and personality traits they expect interns to possess, and the appeals they use to recruit and motivate interns to work for them without pay. The job ads are significant because they participate in social struggles over the meaning of intern identities at a time when interns are surrounded by controversy and conflict (de Peuter, Cohen and Brophy 2012; Perlin 2012). Stuart Hall (1996, 3) conceptualizes identity as "being constituted within, not outside of representation," a "meeting point" between "the discourses and practices," which "construct us as subjects" and those that attempt to address us as particular kinds of "subjects" (6). This article takes it as axiomatic that reality TV intern job ads are part of a discourse about the intern in society that constructs ideal-type intern subject-positions that address people as prospective interns. My critique, then, aims to unsettle the discursive power that reality TV studios wield over the making of reality TV intern subject-positions, disrupt smooth identifications with these subject-positions, and forward a subject-position of the intern as a worker.

\section{A Capitalist Reality TV Industry}

The reality TV industry is part of capitalism, an economic system in which privately owned companies produce commodities for sale in the market with the intention of making a profit rather than for human need, using privately-owned capital goods (technology) and human labour power (the manual and mental capabilities required to complete tasks) (Mirrlees 2013). In the capitalist system, privately owned and profit-seeking media corporations are the dominant controllers of the means of producing, distributing, and exhibiting reality TV shows (Hearn 2013; Mirrlees 2013). The reality TV industry is comprised of production companies, distribution companies, and exhibition companies, all of which express a class division between the owners (the few people who own and manage the corporation: shareholders and CEOs) and the workers (the many people who labour for the corporation). In general, reality TV production companies manufacture TV shows; reality-TV distribution companies buy the licensing rights to finished TV shows from production firms and sell the use of these TV shows to exhibition companies in specific territories and languages for set periods of time. Production companies make reality TV shows to be sold to distribution companies; distribution companies wholesale the rights to reality TV show to exhibitors; exhibitors make money by delivering TV shows to consumers (via TV network schedules, cable stations, on-demand platforms, and Web-based video streaming sites) in exchange for a subscription fee or consumer attention, which they sell to advertisers. In the reality TV industry, TV distribution/exhibition companies are the consumers of content and TV production companies the sellers, meaning that TV network demand instigates the supply of reality TV shows, which feeds this multi-billion dollar and increasingly consolidated sector (Flint 2014).

In the US, many reality-TV exhibition companies (TV networks) are owned by the biggest six media conglomerates: Walt Disney Company (ABC), Time-Warner (HBO, CNN, TNT, truTV), News Corporation (Fox), NBC-Universal (NBC TV, Bravo, CNBC, USA Network), CBS 
Corporation (CBS TV, the CW, Showtime), and Viacom (MTV Networks, BET Networks, Spike) (Mirrlees 2013). Some of these conglomerate-owned TV exhibitors acquire reality TV shows from "in-house" TV studios. Warner Brothers, for example, has an Unscripted and Alternative Television division and $21^{\text {st }}$ Century Fox-owned Shine America produces reality-TV programming for Fox Networks. Most of the time, however, major TV exhibitors acquire reality TV shows that are flexibly produced "out-of-house" by studios operating in a semi-independent reality TV production/distribution sector. Among the largest of these are Freemantle North America, Endemol North America, Mark Burnett's One Three Media, Gordon Ramsay's One Potato Two Potato, and Ryan Seacrest's Ryan Seacrest Productions (Flint 2014; O'Connel 2014). So, while semi-independent producer/distributor firms control the means of developing reality TV content (and sometimes control the intellectual property to it), convergent media conglomerates control the major exhibition pipes through which reality TV shows flow to viewers. TV networks (the buyers) have the upper hand in the exchange relationship with reality TV studios (sellers), and in response to network-driven demand for cheap-to-acquire content, studios compete against each other by slashing prices and, consequently, driving down the cost of labour (Carter 2003; Hearn 2014; Slocum 2014). Reality TV shows are pervasive because they are "cheap" to buy relative to more expensive scripted TV shows, but at the base of impersonal market transactions between TV networks and TV studios and the scheduled consumption of the latest reality hit, is the capitalist exploitation of human labour, both waged and unwaged.

The reality TV industry is "paradigmatic" of post-Fordist neoliberal capitalism's flex production model and exploits low to no-waged workers as a way to maximize profits (Andrejevic 2004, 2011; Hearn 2008, 2010, 2014; Raphael 1997; Ross 2014; Waxman 2005). Behind the scenes of reality TV shows, non-unionized workers toil overtime without pay, lack health insurance and pensions, subsist on short-term contracts, and flexibly move from one project to the next, some lasting weeks, others, many months (Hearn 2014; Raphael 1997; Ross 2014). And in the contrived scenes of reality TV shows, many people create the content we see but few are actually paid for their performances (Collins 2008; Hearn 2014). Although reality TV studios rely on the labour of "dispensable celebrities" (Collins 2008) to make TV shows, they use "participation agreements" to get the people who appear in the scenes to voluntarily exculpate their rights to compensation, privacy, free speech, an attorney, and even the content of their labor (Blair 2010; Cianci 2009; Collins 2008; Hearn 2014; Kelley 2006). These dispensable celebrities will endure this largely unpaid work to cultivate "branded selves" that they hope to exchange for "attention, reputation, and potentially profit" in the future (Hearn 2014, 446). While scholars have scrutinized the reality TV production sector's exploitation of low- to no-waged workers, they have not yet addressed how the work of unpaid interns may feed this sector's bottom line. To illuminate the "blindspot" of internships in the capitalist reality TV industry, the following section demonstrates how internships are an important part of reality TV's division of labour.

\section{The Intern as a Skilled Worker in the Reality TV Studio's Division of Labour}

In the reality TV industry, studios conceptualize, produce, and sell/license the TV shows they make, and organize and administer the financial, technological, and human relations required to produce reality TV shows. The primary goal of all reality TV production companies is to accumulate profit by selling reality TV shows as commodities in TV distribution/exhibit markets for more than it costs to make them. But to make reality TV shows, companies need technology and the skills and talents of many workers. No one reality TV show is produced by a single corporate "author," but rather, is the result of many workers who are part of each studio's division of labour. In each reality TV studio's division of labour, hundreds of workers perform specific roles and complete various tasks that contribute to the manufacture of reality TV shows. 
For example, studios rely on producers to develop the TV show format and production managers and assistants to support format research and development. Studios depend upon casting agents to scout, interview, and cast people to appear in the shows. Studios need directors to direct the action, videographers to shoot it, lighting technicians to light it, and musicians to create the theme music. They rely upon set-makers, sound technicians, visual effects-makers, make-up artists, hair stylists, and wardrobe workers. In post-production, studios need editors to transform thousands of hours of film into TV-schedule ready content. Supporting each of these roles and tasks are a number of clerical workers. Reality TV's division of labour is indeed multi-faceted, and as of late, studios are hiring interns to do jobs previously done by paid TV workers.

Table 1, Reality TV Intern Roles and Tasks, summarizes how the job ads describe the role of the intern in the reality TV studio's division of labour and demonstrate that these interns perform a number of roles and complete a variety of tasks that support the production of reality TV shows. Nine of the job ads for interns are for production assistants (45 percent of the postings), three are for casting agents (15 percent), two are for videographers, one is for clerical support, one is for a post-production editor, one is for a combined intern videographer/post-production editor, one is for a hybrid internal clerical worker and production assistant, and two do not specify the role the interns will play. According to the ads, reality TV interns imagine, research, and develop new reality TV show concepts for studios; write, review, and edit the scripts of reality TV episodes; search for, attract, interview, and cast the people who appear in the content of reality TV shows; set up scenes to be shot and coordinate lighting for shoots; film the action and interactions of contestants and participants; and digitize, craft, and edit footage into TVschedule ready segments in post-production. From content development to shooting to postproduction, reality TV interns cover the gamut of roles and tasks in reality TV's division of labour. Yet the intern is often defined by companies as anything but a worker who does real work (Perlin 2012). However, as the job postings indicate, reality TV interns are actually workers because they contribute in significant ways to the production of reality TV commodities. The reality TV intern's labour helps to create the content of the TV properties that studios own, control, and sell.

In the reality TV industry, studios seek to harness the skills of many workers and channel them toward TV commodity production. "Hard skills" tend to refer to technical abilities (i.e., verbal and written communication, the ability to use hardware and software) and "soft skills" connote interpersonal competencies (i.e., etiquette, affect, positivity, and reflexivity) (Heckman 2012). Table 2, Reality TV Intern Skills: Hard and Soft, summarizes how the reality TV intern job ads represent the combined hard and soft skills that studios expect people to possess as a prerequisite to considering them eligible for internships. Seventeen of the ads require applicants to possess hard technical skills ( 85 percent), 18 ask for soft skills (90 percent), and 14 request a combination of hard and soft skills (70 percent). In the category of hard skills, six ads demand communication skills (verbal and written; 20 percent), one asks for only computer literacy skills, two call for videography skills, and seven want applicants to possess a combination of communication, computer literacy, and videography skills (35 percent). Four of the ads do not say that applicants need to possess hard skills (20 percent). In the category of soft skills, the job ads represent interns as possessing a bundle of interpersonal competencies: 10 ads say applicants must have a "positive attitude" as indicated by phrases like "fun loving" and personality descriptors such as "amicable" and "likable" (50 percent); nine want efficient interns, as highlighted by phrases such as "complete assignments in a timely manner" (45 percent); eight call for self-motivated interns with phrases like "can do attitude" and "make it happen person" (40 percent); seven emphasize intellectual acuity and adaptability with phrases like "eager to learn," "fast learner," and "able to think on their feet" (35 percent); seven want "creative" interns as implied by phrases like "out of the box thinker" and "abstract thinker" (35 percent); seven require applicants to be passionate about entertainment as suggested by 
phrases like "strong passion for pop culture genre" (35 percent); four want interns to be multitaskers (20 percent); four want trustworthy interns ( 20 percent); four call for interns with strong organization skills (20 percent); three want flexible interns that can "wear lots of different hats" and "switch gears at a moment's notice" (15 percent); three emphasize that interns should be able to work independently, while another three stipulate interns should be able to take directions; three want dependable interns; three call for team-working and collaborative interns; two ask that applicants be detail oriented; two emphasize leadership skills; and three ads emphasize that interns should have problem-solving skills, analytical skills, and confidence. In sum, the ads construct the reality TV intern as a skilled cultural worker who does creative, emotional, and knowledge labour that contributes to the production of the TV shows that studios own and sell as commodities in TV distribution/exhibition markets.

"Internship" is ostensibly a synonym for "experiential education, volunteer work, participant observation, training, or apprenticeship" (Perlin 2012, 206) that equips aspiring workers with the skills they need to compete for a paid job. But as the reality TV intern job postings indicate, reality TV interns are not simply students, volunteers, participants, trainees or apprentices that accumulate the skills they need to compete for a reality TV industry career. Rather, they are workers who must already possess the skills required to perform roles and complete tasks in the reality TV industry's division of labour. Indeed, to be considered eligible for an internship in the reality TV industry, the applicant must convince the studio that they possess hard skills covering communication, computer literacy, and videography. Moreover, they are expected to have soft skills like abstract thinking and problem solving, as well as display emotional intelligence and positive affect. The reality TV intern job profile bundles together seemingly contradictory skills that place tremendous demands upon the worker's mind, body, and time. Studios want their interns to be able to complete specific tasks and multi-task, to lead and be led, to direct and take directions, to work alone and together in groups, to be creative yet detailed oriented, and to be passionate about reality TV and happy to produce it, just without pay. The reality TV studio demand that interns possess the aforementioned skills flies in the face of the notion that the internship is just an opportunity to gain skills or upskill. When juxtaposed with the fact that reality TV studios expect their interns to already possess a combination of hard and soft skills before hiring them, the idea that these internships equip people with the skills required to compete for a real waged job or career in the reality TV industry rings false and suggests that reality TV's interns are already skilled workers, just not being classified as such. Reality TV internships may not equip people with new skills, but rather, enable studios to harness the existing skills of workers and apply them to commodity production. But are reality TV interns paid for their labour, and if not, why might they consent to work without wages?

\section{The Capital-Labour Relationship: Reality TV Interns Work for Experience}

In the capitalist reality TV industry, there are owners of reality TV studios and workers who sell their labour power to them in exchange for a wage. The wage power relationship between owners and workers appears to be "free" (because studios do not technically coerce workers to work for wages) and "equal" (because studios and workers meet in the market as individualized sellers and buyers of commodified labour). Yet, apropos Marx (1990), the capital-labour relationship is substantively unfree and unequal. In capitalist economies, all workers largely depend upon their wages to live, which means that they must sell their labour power to companies as a commodity in exchange for the wage they require to buy their basic needs. And though the owners and the workers may both enjoy juridical equality as individual citizens in a liberal democratic state, the formal equality established and upheld by the state's legal apparatus masks substantive socio-economic inequalities, class inequality in particular (Mooers 2014). So, this ostensibly "free" and "equal" exchange relationship mystifies a substantively asymmetrical power relationship between reality TV owners and workers typified by capitalism's 
silent compulsion of waged work (i.e., the worker must labour for a company to meet their needs) and the unequal outcome (i.e., the worker's labour is exploited by companies to enrich its owners, which reproduces class division and inequality).

Although a typical capital-waged labour relationship persists in the reality TV industry (Hearn 2014; Ross 2013), the relationship between the reality TV studio and the reality TV intern is not based on the wage. Table 3, The Characteristics of the Reality TV Internship, demonstrates that only two of the surveyed reality TV production studios (Stick Figure Productions and Whalerock Industries) pay their interns a wage for the jobs they do. Another two (Half Yard Productions and Vantage Media) offer their interns an undisclosed stipend following their completion of the internship. The remaining 15 companies do not offer their interns any monetary compensation. Thus, 0.5 percent of reality TV internships surveyed by this study pay a minimum wage; 10.5 percent pay a stipend, which often equals less than minimum wage; 79 percent are not paid. These findings underscore a capital-unwaged labour relationship between the studio owners and interns qua workers. Even though reality TV interns may possess the manual and mental capabilities required to make reality TV shows and do real work for profit-oriented studios, they toil in the absence of monetary compensation for their efforts. Yet, the relationship between the reality TV owners and workers still appears to be "free" (because studios do not force workers to do internships or to complete numerous value adding tasks) and "equal" (because studios and the workers meet in an ostensibly benign exchange relationship). The ostensibly "free and equal" capital-unwaged labour relationship between reality TV studios and the interns nonetheless masks a substantively asymmetrical relationship that upholds the power and profits of companies at the expense of the workers, who do not get paid for their creative labour.

In studies of the work that prosumers do for social media corporations, "free labour" (content generation) is sometimes conceptualized as a private hobby, un-alienated leisure activity or form of voluntary practice set apart from the realm of necessity (Terranova 2004). Yet, the notion that online "free labour" is purely voluntary as opposed to compulsory risks misconstruing it as something set apart from capitalist exploitation of labour for profit (Fuchs 2014). In the context of unpaid internships generally and reality TV internships in particular, this unwaged labour is something that aspiring waged workers may feel pressured to do in the present as a precondition for struggling to meet their subsistence needs in the future. Many culture industry corporations expect workers to pull themselves up from unpaid internships to the world of waged work prior to even considering them and their labour power worthy of a wage. When people "freely" choose to do unpaid reality TV internships, the silent compulsion of waged labour does not disappear, but rather, may act as the future-oriented goal that compels people to work without pay in the present.

Additionally, "few people can afford to work for free" (de Peuter, Cohen and Brophy 2012), and for this reason, internships privilege some workers at the expense of others, including some and excluding others (Perlin 2012). For the privileged workers who benefit from extra-economic support systems like wealthy families and do not rely on waged jobs to make ends meet, the reality TV intern experience may help them to achieve their goal of waged work later on. But for those less well-off workers who cannot in the present afford to trade labour power for experience and who must work waged jobs to live, the reality TV internship may not be feasible. In this respect, the reality TV internship reproduces existing class divisions by enabling the already privileged to acquire the "experience" and connections required to be considered employable while keeping the less privileged workers out of the game and trouncing their employability.

Furthermore, the relationship between reality TV studios and intern-workers is fundamentally unequal. The studio, not the worker, determines the worker's role, tasks, and time in the division of labour; the studio, not the worker, decides the skills the worker must possess as a prerequisite for being considered hireable; and the studio, not the worker, controls the intellectual property rights to the TV shows workers produce and turn a profit by selling them in 
markets. In sum, the ostensibly "free" and "equal" exchange relationship between the reality TV studio and intern worker obscures asymmetrical power relations of class (the owner-worker division), compulsion (the worker may feel pressured to gift their labour to the studio in order to gain the experience they need to possibly get a wage in the future), exclusion (most workers cannot feed or shelter themselves with "experience" and without financial support from family or government), unfreedom (the worker's role, tasks, and time are decided and controlled by the studio), and inequality (the worker is exploited to produce commodities whose sale further helps owners to prosper).

Given these objectively bad conditions, why might workers do reality TV internships? Academic credit might be one factor, and 12 of the ads frame the internship as offering academic credit (60 percent). But the remaining eight do not say whether or not the internship provides academic credit (40 percent), and the subjective motivation for the unwaged reality TV internship may be deeper. Political economists, for example, have shown how workers will consent to work without wages in exchange for symbolic rewards like peer recognition, selfactualization, or exposure (Cohen 2008, 2012; Deuze 2007; Hesmondhalgh 2010; Huws 2007, 2010; Ross 2009, 2014; Terranova 2004). Kathleen Kuehn and Thomas Corrigan $(2013,9)$ developed the concept of "hope labour" to explain the subjective dimension of unwaged work, defining this as "un- or under-compensated work carried out in the present, often for experience or exposure, in the hope that future employment opportunities may follow." Kuehn and Corrigan (2013) claim that hope is an ideology that gets workers to actively consent to unwaged labour for a media company (16-17) and is also a coping strategy that workers rely upon to negotiate "the uncertainties of the contemporary labour economy" (10). Although Kuehn and Corrigan (2013) centre on how the hope labour of digital content producers enables digital media companies to "avoid costs associated with content producers' wages and benefits" (20) while shifting "costs and risks" onto the unwaged worker (21), they say that "hope labor is not restricted to digital spaces" (15) and mention "hope labor's recent proliferation" within and beyond the cultural industries. They flag reality TV and internships as non-social media sites for examining its workings (15).

As detailed in Table 4, The Reality TV Intern Experience, most of the reality TV intern ads support the workings of "hope ideology" by framing the unwaged internship as providing aspiring waged workers with a positive career-relevant experience of some sort. Twelve of the ads (60 percent) frame the internship as a way for the worker to train for a TV industry career or acquire skills related to one by using phrases like "hands on experience" and "learn about TV and film development process first hand." Eight of the ads (40 percent) emphasize that the internship gives the worker a chance to expose themselves to industry insiders and network with professionals by deploying phrases like "gain exposure [ . . . ] and network" and "pick the brains of the leadership team." Eight of the ads (40 percent) represent the internship as a chance to be mentored by an industry leader, as suggested by phrases like "work directly with Tina Eisner, the casting Manager," "work closely with Brandi Walker Maddox" and work "with the President of the company." Clearly, the reality TV intern job ads frame the internship as a career-relevant experience that will help the worker to develop a range of skills, expose themselves to and network with industry insiders, peers, and professionals, and even be mentored by managers. By representing reality TV internships as providing a positive career relevant experience, the reality TV intern job ads may persuade prospective applicants that working for free for a reality TV studio might really help them to secure gainful waged employment within the TV industry later on. And the worker's hope that the experience they get by doing the reality TV internship will help them get a paid career in the future may encourage them to enthusiastically consent to as opposed to contest the objective fact that studios are misclassifying them as interns to dispossess their labour power, devalue the labour of all workers in this sector, and displace formally paid employees. 


\section{Conclusion: Reality TV Intern Class Action}

By interrogating 20 reality TV internship job ads for internships in the US-based, yet globalizing, reality TV production sector, this article demonstrates that reality TV studios embrace, exploit, and try to elicit the consent of workers to low to no waged work via internship programs. Although the power relationship between reality TV studios and workers is marked by division, compulsion, exclusion, unfreedom, and inequality, the ideology of "hope" for a career-relevant experience may persuade workers to accept rather than challenge these capitalist conditions.

Yet, reality TV interns are not dupes of capital, but agents who possess the collective capacities for understanding and changing their conditions, and for the better. Across the cultural industries, workers are spearheading an "emerging intern activism" by blowing the whistle on the companies that exploit them, working with unions, launching class action suits, and pressuring government to crack down on illegal programs (de Peuter, Cohen and Brophy 2012; Perlin 2012; Yamada 2013b). Perhaps the most effective way that workers have contested unpaid internships is through litigation, as highlighted by a number of high-profile intern class action suits in the United States against media corporations like Fox Searchlight, the Hearst Corporation, Condé Nast, Warner Music Group, Sirus, and Vice Media (Sterne 2014). By proving that media corporations misclassified them as interns and used them to replace paid employees, workers have won back wages for the labour they did as "interns" (de Peuter, Cohen and Brophy 2012). The most significant legal battle surrounding the rise of "intern nation" (Perlin 2012), then, centers on the power to define the intern as an "employee" or "non-employee."

According to the US Equal Employment Opportunity Commission and the Civil Rights Act, people who are not paid for the work they do are not classified as "employees," hence, the people who do unpaid internships are "non-employees" and have no "human rights" in the workplace (Perlin 2012, 78; Yamada 2013a, 2013b). Yet, the US Federal Fair Labor Standards Act (FLSA) defines an "employee" as "any individual employed by an employer" with "employ" meaning "to suffer or permit to work," and thus, when a company employs a person's labour, even when not paying them, they are dealing with employees who possess human rights, including the right to be paid a minimum wage (Nieves 2014). Furthermore, the US Department of Labor (DOL) uses six criteria for determining whether or not a company is misclassifying employees as interns: 1) the internship is similar to the training an educational environment would provide; 2) the internship is for the benefit of the intern; 3 ) the intern does not displace regular employees; 4) the employer derives no immediate advantage from the intern; 5) the intern is not entitled to a job at the end of the internship; 6 ) the intern understands that he or she is not entitled to wage (Carrigan 2012; Nieves 2014). If the company running the unpaid internship program fails to meet all of these six criteria, their interns are legally classifiable as employees and must be paid.

To date, interns have not launched any class action suits against reality TV studios. Yet, there may be solid grounds for such a case. With regard to the FLSA's definition, reality TV interns are classifiable as employees of studios because they do real work for them. And when put to the DOL's six-point test, reality TV studios would seem to get a failing grade, for reasons outlined below.

First, reality TV internships are not similar to the training an educational environment would provide with regard to context because colleges and universities are not privately owned forprofit TV studios that get students to produce reality TV show commodities. Also, training connotes a process whereby a mentor teaches a particular skill to an apprentice so as to prepare them to do certain types of work, but reality TV studios expect their interns to already possess skills prior to putting them to work. Second, reality TV internships may benefit the people who do them by providing "experience" to put on their résumé, a letter of reference, and a sense of how reality TV production happens, but these benefits are equivalent to what any 
entry-level reality TV studio employee would obtain by doing the work that interns do, so it is not apparent that reality TV studios intentionally design and run unpaid internship programs exclusively for the moral betterment or educational uplift of workers. As discussed earlier, these internships may perpetuate capitalist power relations of class division, compulsion, exclusion, unfreedom, and inequality that do not benefit interns, but instead advance the interests of reality TV studios. Third, reality TV interns perform significant roles in the reality TV industry's division of labour that would have been played by employees and complete tasks employees would get paid to do. If reality TV studios did not have interns to play productive roles and complete tasks without pay at their disposal, they would likely have to hire and pay more employees to make their TV shows. Fourth, reality TV studios derive an immediate advantage from the intern because they channel the intern's skills into the production of reality TV shows that they own the property rights to and sell for a profit in the TV market-reality TV studios exploit the labour of interns for their own financial gain. Fifth, reality TV interns do not appear to be entitled to a job at the end of the unpaid internship, but this obscures how reality TV internships are basically jobs that do not pay. Sixth, although the reality TV intern job ads make it clear to applicants that they will not be paid for their labour, given that studios seem to be misclassifying employees as interns, this is irrelevant; under the FLSA, employees are not allowed to waive their right to be paid a wage for work.

In conclusion, workers have solid grounds for a class action suit against the reality TV studios, which misclassify them as interns and a right to recuperate lost wages for the real work they do. A more substantive case for workers against reality TV studios that solidifies the preliminary one posited herein will depend upon workers themselves gaining the confidence to publicly speak out about their experiences. Yet, the prospect of speaking truth to capitalist power may intimidate interns, especially in these precarious times and in such a competitive TV labour market. Fear of being stigmatized as a militant intern, blacklisted by internship program managers, and deprived of their shot to work for free as a means to maybe one day be employed for a wage, may deter interns from speaking out. Moving forward, the lawyers and unions involved in intern activism should have dialogue with such workers. And labour-minded communication studies scholars could gain further knowledge about and publicize how these workers live and labour by doing ethnographic research. A record of the feelings, thoughts, and testimonies of the workers that the reality TV industry embraces to exploit as unpaid interns would be a valuable supplement to this study and provide new cultural material to either validate or challenge its critique.

\section{Appendix A: Reality TV Intern Job Search}

Table 1. Reality TV Intern Roles and Tasks

\begin{tabular}{|l|l|l|l|l|}
\hline Company & Intern Role/ Tasks & $\begin{array}{l}\text { Production } \\
\text { Assistant } \\
\text { "develop and pitch } \\
\text { non-scripted } \\
\text { shows," "creating } \\
\text { new ones [shows]" } \\
\text { "researching for } \\
\text { existing shows" } \\
\text { "reality TV screen } \\
\text { writing" }\end{array}$ & $\begin{array}{l}\text { Casting } \\
\text { "cast [ ... ] non- } \\
\text { scripted shows" } \\
\text { "telephone } \\
\text { interviewing } \\
\text { skills, skyping } \\
\text { interviewing }\end{array}$ & $\begin{array}{l}\text { "general } \\
\text { office support } \\
\text { (phones, } \\
\text { copies, } \\
\text { etc...) }\end{array}$ \\
\hline CK Global Trading & $\begin{array}{l}\text { "Screen } \\
\text { Writer/Reality TV } \\
\text { Shows" }\end{array}$ & & & \\
\hline
\end{tabular}




\begin{tabular}{|c|c|c|c|c|}
\hline & & & potential talent" & \\
\hline Cornwell Casting & "Casting Intern" & & $\begin{array}{l}\text { "help with } \\
\text { finding } \\
\text { applicants, } \\
\text { greeting them } \\
\text { when they come } \\
\text { in for interviews, } \\
\text { preparing } \\
\text { pitches, and } \\
\text { more" }\end{array}$ & \\
\hline $\begin{array}{l}\text { Forever Fabulous } \\
\text { Events }\end{array}$ & "Office Intern" & & & $\begin{array}{l}\text { "organize } \\
\text { and collect } \\
\text { progress } \\
\text { reports," } \\
\text { "monitor } \\
\text { project } \\
\text { calendar, } \\
\text { ensuring } \\
\text { project is on } \\
\text { schedule and } \\
\text { in budget" }\end{array}$ \\
\hline Freemantle Media (1) & $\begin{array}{l}\text { "Development } \\
\text { Internship" }\end{array}$ & $\begin{array}{l}\text { "script review and } \\
\text { internal } \\
\text { development } \\
\text { meetings," } \\
\text { "conducting } \\
\text { research as } \\
\text { directed" }\end{array}$ & & $\begin{array}{l}\text { "answering } \\
\text { phones, data } \\
\text { entry, } \\
\text { administrativ } \\
\text { e duties" }\end{array}$ \\
\hline Freemantle Media (2) & $\begin{array}{l}\text { "Scripted } \\
\text { Development } \\
\text { Intern" }\end{array}$ & $\begin{array}{l}\text { "assisting in the } \\
\text { development of } \\
\text { unscripted and } \\
\text { digital projects" }\end{array}$ & & \\
\hline Half Yard Productions & $\begin{array}{l}\text { "Post-Production } \\
\text { Intern" }\end{array}$ & & & $\begin{array}{l}\text { "answering } \\
\text { phones, } \\
\text { transcribing } \\
\text { video } \\
\text { interviews, } \\
\text { logging } \\
\text { actuality } \\
\text { footage and } \\
\text { organizing all } \\
\text { materials to } \\
\text { office } \\
\text { management }\end{array}$ \\
\hline Hart18 Entertainment & "Casting Intern" & & $\begin{array}{l}\text { "researching, } \\
\text { finding, and } \\
\text { pitching new } \\
\text { prospective } \\
\text { talents for new } \\
\text { projects," } \\
\text { "posting casting } \\
\text { calls" }\end{array}$ & $\begin{array}{l}\text { "sending, } \\
\text { vetting and } \\
\text { sorting a } \\
\text { variety of } \\
\text { email" }\end{array}$ \\
\hline HillCrest Event Center & $\begin{array}{l}\text { "TV Camera } \\
\text { Person/Videograph }\end{array}$ & $\begin{array}{l}\text { "assist in scene set } \\
\text { up", "assist in }\end{array}$ & & \\
\hline
\end{tabular}




\begin{tabular}{|c|c|c|c|}
\hline & er Intern" & $\begin{array}{l}\text { lighting } \\
\text { coordination," } \\
\text { "assist during } \\
\text { events and } \\
\text { receptions," } \\
\text { "maintain camera } \\
\text { equipment," "hand } \\
\text { valuable camera } \\
\text { equipment" }\end{array}$ & \\
\hline JBO Production Inc. & $\begin{array}{l}\text { "Videographer/post- } \\
\text { production editor } \\
\text { Intern" }\end{array}$ & $\begin{array}{l}\text { "capturing, logging } \\
\text { and digitizing video } \\
\text { footage from } \\
\text { multiple formats," } \\
\text { "assist in } \\
\text { assembling rough } \\
\text { cuts for national TV } \\
\text { shows," "help with } \\
\text { miscellaneous } \\
\text { projects," "assist on } \\
\text { video shoots" }\end{array}$ & \\
\hline $\begin{array}{l}\text { Lighthearted } \\
\text { Entertainment }\end{array}$ & $\begin{array}{l}\text { "Office and } \\
\text { Development } \\
\text { Intern" }\end{array}$ & $\begin{array}{l}\text { "supporting the } \\
\text { development team" } \\
\text { "heavy emphasis } \\
\text { on researching } \\
\text { existing show } \\
\text { ideas" }\end{array}$ & $\begin{array}{l}\text { "general } \\
\text { office support } \\
\text { (phones, } \\
\text { copies, etc.)" }\end{array}$ \\
\hline $\begin{array}{l}\text { On-Ride } \\
\text { Entertainment, LLC }\end{array}$ & $\begin{array}{l}\text { "Videographer } \\
\text { Intern" }\end{array}$ & $\begin{array}{l}\text { "videographer," } \\
\text { "participate in focus } \\
\text { groups and panels [ } \\
\text {... ] to help further } \\
\text { develop the series," } \\
\text { "may also } \\
\text { participate in the } \\
\text { editing process" }\end{array}$ & \\
\hline $\begin{array}{l}\text { One Potato Two } \\
\text { Potato }\end{array}$ & Not specified & $\mathrm{N} / \mathrm{A}$ & \\
\hline $\begin{array}{l}\text { Ryan Seacrest } \\
\text { Productions }\end{array}$ & Not specified & $\begin{array}{l}\text { "diversified } \\
\text { selection of } \\
\text { assignments with } \\
\text { an emphasis on } \\
\text { projects, rather } \\
\text { than clerical tasks" } \\
\text { "assisting with } \\
\text { special projects } \\
\text { related to Red } \\
\text { Carpet events and } \\
\text { Unscripted } \\
\text { Television } \\
\text { Development" }\end{array}$ & \\
\hline Sonassa's LLC & $\begin{array}{l}\text { "Videography Intern } \\
\text { for Reality and } \\
\text { Television Show" }\end{array}$ & $\begin{array}{l}\text { "film a weekly } 30 \\
\text { minutes Television } \\
\text { Show which } \\
\text { includes } 15 \text { minutes } \\
\text { of the Talk Show } \\
\text { and } 15 \text { minutes of }\end{array}$ & \\
\hline
\end{tabular}




\begin{tabular}{|c|c|c|c|c|}
\hline & & $\begin{array}{l}\text { the Reality Show," } \\
\text { "the end product } \\
\text { should be } \\
\text { comparable to } \\
\text { mainstream } \\
\text { Television show" }\end{array}$ & & \\
\hline $\begin{array}{l}\text { Stick Figure } \\
\text { Productions }\end{array}$ & "Production Intern" & $\begin{array}{l}\text { "help in all aspects } \\
\text { of our production } \\
\text { company," } \\
\text { "developing } \\
\text { projects," "working } \\
\text { on projects } \\
\text { currently in } \\
\text { production," "help } \\
\text { out with post- } \\
\text { production process" }\end{array}$ & & \\
\hline Superfine Films & $\begin{array}{l}\text { "TV Development } \\
\text { Intern (reality)" }\end{array}$ & $\begin{array}{l}\text { "participate HANDS } \\
\text { on in our reality TV } \\
\text { development } \\
\text { department helping } \\
\text { to develop new } \\
\text { reality television } \\
\text { shows" } \\
\text { "doing research into } \\
\text { creative trends," } \\
\text { "editing" }\end{array}$ & & $\begin{array}{l}\text { "telephone } \\
\text { interviewing," } \\
\text { "skyping and } \\
\text { interviewing } \\
\text { potential } \\
\text { talent" }\end{array}$ \\
\hline The Idea Factory & $\begin{array}{l}\text { "Reality TV } \\
\text { Development } \\
\text { Intern" }\end{array}$ & $\begin{array}{l}\text { "work in } \\
\text { development and } \\
\text { production," } \\
\text { "writing," "shooting," } \\
\text { "possibly editing" } \\
\text { "research" }\end{array}$ & & $\begin{array}{l}\text { "Basic Office } \\
\text { Duties," } \\
\text { "phones" }\end{array}$ \\
\hline Vantage New Media & $\begin{array}{l}\text { "Production } \\
\text { Assistant } \\
\text { Internship" }\end{array}$ & $\begin{array}{l}\text { "pre-to-post } \\
\text { production of a } \\
\text { segment of a } \\
\text { Nationwide Reality } \\
\text { Television Program } \\
\text { focused on the } \\
\text { making of College } \\
\text { Swimsuit } \\
\text { Calendars" }\end{array}$ & $\begin{array}{l}\text { "full involvement } \\
\text { in the casting } \\
\text { process" }\end{array}$ & \\
\hline Whalerock Industries & $\begin{array}{l}\text { "TV/Film } \\
\text { Development } \\
\text { Intern" }\end{array}$ & $\begin{array}{l}\text { "Participate in } \\
\text { creative } \\
\text { development } \\
\text { meetings with } \\
\text { Scripted and } \\
\text { Unscripted TV } \\
\text { executives," "Work } \\
\text { on projects in } \\
\text { development for } \\
\text { various television } \\
\text { networks and } \\
\text { media outlets" }\end{array}$ & & \\
\hline
\end{tabular}

Table 2. Reality TV Intern Skills: Hard and Soft 


\begin{tabular}{|c|c|c|}
\hline Company & Hard Skills & Soft Skills \\
\hline Beyond Productions & $\begin{array}{l}\text { "excellent } \\
\text { communication } \\
\text { skills" }\end{array}$ & $\begin{array}{l}\text { "initiative," "organized," "able to multi-task," "positive } \\
\text { attitude," "quick learner," "creative" }\end{array}$ \\
\hline CK Global Trading & $\begin{array}{l}\text { "must have } \\
\text { experience in } \\
\text { reality TV screen } \\
\text { writing" }\end{array}$ & $\begin{array}{l}\text { "out of the box thinker/writer," "be able to put the } \\
\text { society under critical camera lens," "work as a team," } \\
\text { "share her/his/ idea to other team members to the } \\
\text { point of completion on time" }\end{array}$ \\
\hline Cornwell Casting & $\begin{array}{l}\text { "knowledge of } \\
\text { editing software," } \\
\text { "Photoshop, and or } \\
\text { Powerpoint," } \\
\text { "excellent written } \\
\text { and verbal skills" }\end{array}$ & $\begin{array}{l}\text { "highly motivated," "ambitious," "positive and eager } \\
\text { attitude" }\end{array}$ \\
\hline $\begin{array}{l}\text { Forever Fabulous } \\
\text { Events }\end{array}$ & & $\begin{array}{l}\text { "assessing issues, defining solutions, and } \\
\text { implementing strategy," "how to implement goals," } \\
\text { "leadership, efficiency, dependability and } \\
\text { organization" }\end{array}$ \\
\hline Freemantle Media (1) & $\begin{array}{l}\text { "strong computer } \\
\text { skills," "proficient in } \\
\text { PC, Microsoft } \\
\text { Office and other } \\
\text { programs" }\end{array}$ & $\begin{array}{l}\text { "detail oriented, eager to learn and efficient, with } \\
\text { excellent follow-up and follow-through skills," "multi- } \\
\text { task, take initiative, be naturally curious, fun loving," } \\
\text { "trustworthy with sensitive and confidential } \\
\text { information" }\end{array}$ \\
\hline Freemantle Media (2) & $\begin{array}{l}\text { "knowledge of } \\
\text { editing software, } \\
\text { Photoshop, and/or } \\
\text { PowerPoint is a } \\
\text { plus," "excellent } \\
\text { written and verbal } \\
\text { skills" }\end{array}$ & "ambitious," "positive and eager attitude" \\
\hline Half Yard Productions & $\begin{array}{l}\text { "strong } \\
\text { communication } \\
\text { skills" }\end{array}$ & $\begin{array}{l}\text { "meticulous, flexible and ready to work in a fast paced } \\
\text { office" }\end{array}$ \\
\hline Hart18 Entertainment & "terrific email skills" & $\begin{array}{l}\text { "Organizational skills," "The ability to meet deadlines," } \\
\text { "follow specific directions," "ability to work } \\
\text { independently," "strong interest in TV and media," } \\
\text { "previous internship experience preferred, but not } \\
\text { necessary" }\end{array}$ \\
\hline HillCrest Event Center & $\begin{array}{l}\text { "working knowledge } \\
\text { of basic camera } \\
\text { operation," "Adobe } \\
\text { Master Collection } \\
\text { and Microsoft," } \\
\text { "excellent written } \\
\text { and verbal } \\
\text { communication" }\end{array}$ & $\begin{array}{l}\text { "multi-tasking and coordination," "passion for art and } \\
\text { film," "attention to details while maintaining } \\
\text { perspective," "able to give and take direction," "artistic } \\
\text { vision," "work in fast paced environment" }\end{array}$ \\
\hline JBO Production Inc. & & $\begin{array}{l}\text { "highly motivated," "reliable," "dedicated," } \\
\text { "enthusiastic" }\end{array}$ \\
\hline $\begin{array}{l}\text { Lighthearted } \\
\text { Entertainment }\end{array}$ & $\begin{array}{l}\text { "Mac skills," } \\
\text { "excellent } \\
\text { communication" }\end{array}$ & $\begin{array}{l}\text { "follow through," "excellent organizational, analytical } \\
\text { and prioritization skills," "quick learner," "multi-tasker," } \\
\text { "fast, quality-reinforced turnaround," "positive } \\
\text { attitude/sense of humor," "ability to maintain } \\
\text { confidentiality" }\end{array}$ \\
\hline $\begin{array}{l}\text { On-Ride Entertainment, } \\
\text { LLC }\end{array}$ & $\begin{array}{l}\text { "sufficient } \\
\text { experience using }\end{array}$ & \\
\hline
\end{tabular}




\begin{tabular}{|c|c|c|}
\hline & $\begin{array}{l}\text { DSLR camera for } \\
\text { filming," "owner of } \\
\text { DSLR camera" }\end{array}$ & \\
\hline One Potato Two Potato & $\begin{array}{l}\text { "Working } \\
\text { knowledge of Final } \\
\text { Cut Studio," } \\
\text { "Proficient in all } \\
\text { Office applications," } \\
\text { "Advanced Post } \\
\text { Production software } \\
\text { knowledge a plus," } \\
\text { "Excellent } \\
\text { communication } \\
\text { skills both verbal } \\
\text { and writing" }\end{array}$ & $\begin{array}{l}\text { "Reliable," "Honest", "Hardworking," "Proactive 'can } \\
\text { do' attitude," } \\
\text { "Interest in Television production and development," } \\
\text { "Extremely organized" }\end{array}$ \\
\hline $\begin{array}{l}\text { Ryan Seacrest } \\
\text { Productions }\end{array}$ & $\begin{array}{l}\text { "Proficient in MS } \\
\text { Office applications," } \\
\text { "previous } \\
\text { experience in } \\
\text { WordPress a plus," } \\
\text { "excellent } \\
\text { communication } \\
\text { skills" }\end{array}$ & $\begin{array}{l}\text { "highly-talented and qualified," "Ability to work } \\
\text { independently and as part of a team," } \\
\text { "a focus in broadcast journalism and/or creative } \\
\text { writing," } \\
\text { "strong passion for the pop culture genre including all } \\
\text { things television, film, celebrity, red carpet, music and } \\
\text { digital" }\end{array}$ \\
\hline Sonassa's LLC & $\begin{array}{l}\text { "excellent filming } \\
\text { skills" }\end{array}$ & \\
\hline $\begin{array}{l}\text { Stick Figure } \\
\text { Productions }\end{array}$ & & "Bright," "Ambitious",, \\
\hline Superfine Films & & $\begin{array}{l}\text { "Capable," "Smart, creative," "enthusiasm," "a } \\
\text { confident personality," "a curiosity," "make it happen } \\
\text { person" }\end{array}$ \\
\hline The Idea Factory & $\begin{array}{l}\text { "writing skills," } \\
\text { "video editing } \\
\text { software," "video } \\
\text { compositing and } \\
\text { image editing } \\
\text { programs," "general } \\
\text { layout and design" }\end{array}$ & $\begin{array}{l}\text { "amicable," "highly creative," "able to think on their } \\
\text { feet," "be ready to wear lots of different hats" }\end{array}$ \\
\hline Vantage New Media & $\begin{array}{l}\text { "strong } \\
\text { communication } \\
\text { skills" }\end{array}$ & $\begin{array}{l}\text { "great attitude," "willingness to explore all facets of } \\
\text { the world of entertainment" }\end{array}$ \\
\hline Whalerock Industries & $\begin{array}{l}\text { "a strong writer," } \\
\text { "able to cohesively } \\
\text { summarize and put } \\
\text { feedback and } \\
\text { opinions onto } \\
\text { paper" }\end{array}$ & $\begin{array}{l}\text { "team player," "an avid reader," "be ready to switch } \\
\text { gears at a moment's notice," "self-starter," } \\
\text { "passionate about TV and film," "experience and } \\
\text { knowledge of the TV and film industry is a plus," } \\
\text { "willing to take direction and see assignments through } \\
\text { completion in a timely manner" }\end{array}$ \\
\hline
\end{tabular}

Table 3. The Characteristics of Reality TV Internships

\begin{tabular}{|l|l|l|l|l|l|}
\hline Company & $\begin{array}{l}\text { Number of } \\
\text { positions }\end{array}$ & $\begin{array}{l}\text { Full-timel } \\
\text { Part- } \\
\text { Time }\end{array}$ & Paid & Duration & $\begin{array}{l}\text { Acade } \\
\text { mic } \\
\text { credit }\end{array}$ \\
\hline Beyond Productions & 2 & PT & No & $\begin{array}{l}10 \text { weeks (March 9-May } \\
16,2015)\end{array}$ & Yes \\
\hline CK Global Trading & 10 & PT & No & Ongoing (year round) & Yes \\
\hline
\end{tabular}




\begin{tabular}{|c|c|c|c|c|c|}
\hline Cornwell Casting & 2 & PT & No & Ongoing (year round) & Yes \\
\hline $\begin{array}{l}\text { Forever Fabulous } \\
\text { Events }\end{array}$ & 2 & FT & No & Ongoing (year round) & Yes \\
\hline $\begin{array}{l}\text { Freemantle Media } \\
\text { (1) }\end{array}$ & 1 & PT & No & Ongoing (year round) & Yes \\
\hline $\begin{array}{l}\text { Freemantle Media } \\
\text { (2) }\end{array}$ & 1 & PT & No & Ongoing (year round) & Yes \\
\hline $\begin{array}{l}\text { Half Yard } \\
\text { Productions }\end{array}$ & 1 & PT & $\begin{array}{l}\text { No (but } \\
\text { stipend } \\
\text { provided) }\end{array}$ & $\begin{array}{l}12 \text { weeks (March } 30-J u n e \\
15,2015) \text { 10am,-6pm, } 2 \\
\text { days a week }\end{array}$ & Yes \\
\hline Hart18 Entertainment & 5 & PT & No & 12 weeks & $\mathrm{N} / \mathrm{A}$ \\
\hline $\begin{array}{l}\text { HillCrest Event } \\
\text { Center }\end{array}$ & 1 & PT & No & Ongoing (year round) & $\mathrm{N} / \mathrm{A}$ \\
\hline JBO Production Inc. & 5 & PT & No & Ongoing (year round) & Yes \\
\hline $\begin{array}{l}\text { Lighthearted } \\
\text { Entertainment }\end{array}$ & 6 & PT & No & $\begin{array}{l}\text { Ongoing (year round), 3-5 } \\
\text { days per week }\end{array}$ & Yes \\
\hline $\begin{array}{l}\text { On-Ride } \\
\text { Entertainment, LLC }\end{array}$ & 1 & PT & No & Ongoing (year round) & N/A \\
\hline $\begin{array}{l}\text { One Potato Two } \\
\text { Potato }\end{array}$ & 1 & PT & No & Ongoing (year round) & Yes \\
\hline $\begin{array}{l}\text { Ryan Seacrest } \\
\text { Productions } \\
\end{array}$ & & PT & No & Ongoing (year round) & N/A \\
\hline Sonassa's LLC & 4 & $\mathrm{PT}$ & No & Ongoing (year round) & Yes \\
\hline $\begin{array}{l}\text { Stick Figure } \\
\text { Productions }\end{array}$ & 3 & PT & Yes & Ongoing (year round) & $\mathrm{N} / \mathrm{A}$ \\
\hline Superfine Films & 1 & & No & $\begin{array}{l}12 \text { weeks (March 1-May } \\
22,2015)\end{array}$ & Yes \\
\hline The Idea Factory & 5 & $\mathrm{PT}$ & No & Ongoing (year round) & $\mathrm{N} / \mathrm{A}$ \\
\hline Vantage New Media & 1 & PT & $\begin{array}{l}\text { No (but } \\
\text { "performa } \\
\text { nce- } \\
\text { based } \\
\text { stipend } \\
\text { provided } \\
\text { at } \\
\text { completio } \\
\text { n") }\end{array}$ & Ongoing (year round) & N/A \\
\hline Whalerock Industries & 1 & PT & Yes & $\begin{array}{l}10 \text { weeks (June } 15- \\
\text { August } 21,2015), 3 \text { days } \\
\text { a week. }\end{array}$ & N/A \\
\hline
\end{tabular}

Table 4. The Reality TV Intern "Experience"

\begin{tabular}{|l|l|l|l|}
\hline $\begin{array}{l}\text { Reality TV } \\
\text { Company }\end{array}$ & $\begin{array}{l}\text { Training/Skills } \\
\text { Development }\end{array}$ & $\begin{array}{l}\text { Exposure/ } \\
\text { Networking }\end{array}$ & Mentorship \\
\hline $\begin{array}{l}\text { Beyond } \\
\text { Productions }\end{array}$ & $\begin{array}{l}\text { "the internship is a great } \\
\text { way to learn the industry } \\
\text { and will provide practical } \\
\text { know-how," "hands on } \\
\text { experience in } \\
\text { development of non- } \\
\text { scripted television" }\end{array}$ & $\begin{array}{l}\text { "learn what it takes to create } \\
\text { reality television [ ... ] under our } \\
\text { development team" }\end{array}$ & \\
\hline $\begin{array}{l}\text { CK Global } \\
\text { Trading }\end{array}$ & $\begin{array}{l}\text { "We will teach you the } \\
\text { ins and outs of the }\end{array}$ & $\begin{array}{l}\text { "a unique } \\
\text { opportunity to work }\end{array}$ & $\begin{array}{l}\text { "work directly with Tina Eisner, } \\
\text { the casting manager" }\end{array}$ \\
\hline Cornwell Casting &
\end{tabular}




\begin{tabular}{|c|c|c|c|}
\hline & $\begin{array}{l}\text { casting world and also } \\
\text { provide training on how } \\
\text { to do different types of } \\
\text { casting positions" }\end{array}$ & $\begin{array}{l}\text { with a professional } \\
\text { and experienced } \\
\text { casting team" }\end{array}$ & \\
\hline $\begin{array}{l}\text { Forever Fabulous } \\
\text { Events }\end{array}$ & & & $\begin{array}{l}\text { "work closely with Mrs. Brandi } \\
\text { Walker Maddox interfacing with } \\
\text { all her clients" }\end{array}$ \\
\hline $\begin{array}{l}\text { Freemantle Media } \\
\text { (1) }\end{array}$ & $\begin{array}{l}\text { "A valuable look into the } \\
\text { development process } \\
\text { within a Television } \\
\text { Studio," "a very } \\
\text { educational and } \\
\text { comprehensive look into } \\
\text { the entire TV landscape" }\end{array}$ & & $\begin{array}{l}\text { "the intern will get a chance to } \\
\text { hone their screenplay analysis } \\
\text { skills with guidance from the } \\
\text { development execs" }\end{array}$ \\
\hline $\begin{array}{l}\text { Freemantle Media } \\
\text { (2) }\end{array}$ & $\begin{array}{l}\text { "a great opportunity to } \\
\text { learn about the } \\
\text { unscripted development } \\
\text { process from the ground } \\
\text { up," "an opportunity to } \\
\text { be on set of two game } \\
\text { shows," to "witness first- } \\
\text { hand what it takes to run } \\
\text { a studio based game } \\
\text { show for a major } \\
\text { broadcast network" }\end{array}$ & & \\
\hline \multicolumn{4}{|l|}{$\begin{array}{l}\text { Half Yard } \\
\text { Productions }\end{array}$} \\
\hline $\begin{array}{l}\text { Hart18 } \\
\text { Entertainment }\end{array}$ & & & $\begin{array}{l}\text { "work REMOTELY, directly with } \\
\text { the President of the company" }\end{array}$ \\
\hline $\begin{array}{l}\text { HillCrest Event } \\
\text { Center }\end{array}$ & $\begin{array}{l}\text { "boost your knowledge } \\
\text { of necessary make up } \\
\text { techniques for camera" }\end{array}$ & & $\begin{array}{l}\text { "Assistant to Director of } \\
\text { Photography," "Learn hands on } \\
\text { experience with a group of film } \\
\text { producers" }\end{array}$ \\
\hline $\begin{array}{l}\text { JBO Production } \\
\text { Inc. }\end{array}$ & & $\begin{array}{l}\text { "any projects } \\
\text { worked on by intern } \\
\text { will be provided to } \\
\text { them for demo reel } \\
\text { purposes only" }\end{array}$ & \\
\hline $\begin{array}{l}\text { Lighthearted } \\
\text { Entertainment }\end{array}$ & $\begin{array}{l}\text { "hands on experience in } \\
\text { development of non- } \\
\text { scripted television," "if } \\
\text { you are interested in } \\
\text { getting into reality } \\
\text { television, documentary, } \\
\text { game shows or casting } \\
\text { this will be practical } \\
\text { experience and a great } \\
\text { way to learn the } \\
\text { industry" }\end{array}$ & $\begin{array}{l}\text { "great referent point } \\
\text { for future positions" }\end{array}$ & \\
\hline $\begin{array}{l}\text { On-Ride } \\
\text { Entertainment, } \\
\text { LLC }\end{array}$ & $\begin{array}{l}\text { "expose intern to } \\
\text { structure and processes } \\
\text { involved in producing a } \\
\text { reality TV show" }\end{array}$ & $\begin{array}{l}\text { "great for your } \\
\text { resume!", } \\
\text { "opportunity to } \\
\text { network with }\end{array}$ & $\begin{array}{l}\text { "ability to [ ... . ] shadow } \\
\text { Producers" }\end{array}$ \\
\hline
\end{tabular}




\begin{tabular}{|c|c|c|c|}
\hline & & $\begin{array}{l}\text { Producers and } \\
\text { Directors and } \\
\text { attend focus groups } \\
\text { and corporate } \\
\text { meetings" }\end{array}$ & \\
\hline $\begin{array}{l}\text { One Potato Two } \\
\text { Potato }\end{array}$ & & $\begin{array}{l}\text { "an initial foothold } \\
\text { in television" }\end{array}$ & \\
\hline $\begin{array}{l}\text { Ryan Seacrest } \\
\text { Productions }\end{array}$ & $\begin{array}{l}\text { "hands-on/practical } \\
\text { exposure to the } \\
\text { television/entertainment } \\
\text { industry with a focus on } \\
\text { the Digital Media space" }\end{array}$ & & \\
\hline Sonassa's LLC & $\begin{array}{l}\text { "great opportunity for the } \\
\text { intern to practice their } \\
\text { talent" }\end{array}$ & $\begin{array}{l}\text { "gain exposure [ . . } \\
\text { ] and network with } \\
\text { future prospective } \\
\text { clients" }\end{array}$ & \\
\hline $\begin{array}{l}\text { Stick Figure } \\
\text { Productions }\end{array}$ & $\begin{array}{l}\text { "opportunity to work," } \\
\text { "opportunity of a life- } \\
\text { time" }\end{array}$ & & \\
\hline Superfine Films & $\begin{array}{l}\text { "participate hands on, } \\
\text { creative learning } \\
\text { experiences unlike you } \\
\text { or your friends ever } \\
\text { seen", "Learning...YOU } \\
\text { WILL NOT get coffee, } \\
\text { make copies or pick up } \\
\text { our laundry! Ever..." }\end{array}$ & & $\begin{array}{l}\text { "LEARNING with our } \\
\text { development team" }\end{array}$ \\
\hline \multicolumn{4}{|l|}{ The Idea Factory } \\
\hline \multicolumn{4}{|l|}{$\begin{array}{l}\text { Vantage New } \\
\text { Media }\end{array}$} \\
\hline $\begin{array}{l}\text { Whalerock } \\
\text { Industries }\end{array}$ & $\begin{array}{l}\text { "Learn what it takes to } \\
\text { succeed in the TV/Film } \\
\text { Industry," "Learn about } \\
\text { the TV and film } \\
\text { development process } \\
\text { first hand" }\end{array}$ & $\begin{array}{l}\text { "Have the } \\
\text { opportunity to } \\
\text { develop and pitch } \\
\text { an original idea to } \\
\text { the leadership } \\
\text { team," } \\
\text { "Participate in } \\
\text { 'Lunch \& Learns' - } \\
\text { opportunities to } \\
\text { grab a bite and pick } \\
\text { the brains of the } \\
\text { leadership team" }\end{array}$ & \\
\hline
\end{tabular}

\section{References}

Andrejevic, Mark. 2004. Reality TV: The Work of Being Watched. Lanham, MD: Rowman \& Littlefield. Andrejevic, Mark. 2011. Realizing Exploitation. In The Politics of Reality Television, edited by Marwan. M. Kraidy and Katherine Sender, 18-30. New York: Routledge.

Blair, Jennifer. L. 2010. Surviving Reality TV: The Ultimate Challenge of Reality Show Contestants. Loyola of Los Angeles Entertainment Law Review 31 (1): 1-25.

Brophy, Enda. 2013. Laboring to Learn: Lineaments of the Creative-Academic Complex in Vancouver. Line: $106-111$.

Carrigan, John R. 2012. Hollywood Intern Lawsuits: Overworked, Underpaid And Illegal? Hollywood Reporter, October 25. Accessed December 1, 2014. http://www.hollywoodreporter.com/thresq/hollywood-interns-overworked-underpaid-illegal-382190. 
Cianci, Christopher. 2009. Entertainment or Exploitation? Reality Television and the Inadequate Protection of Child Participants Under the Law. Southern California Interdisciplinary Law Journal 18 (1): 363-94.

Cohen, Nicole. 2012. Cultural Work as a Site of Struggle. triple C 10(2): 141-155.

Cohen, Nicole. 2008. The Valorization of Surveillance: Toward a Political Economy of Facebook. Democratic Communiqué 22 (1): 5-22.

Collins, Sue. 2008. Making the Most out of 15 Minutes: Reality TV's Disposable Celebrity. Television \& New Media 9 (2): 87-110.

de Peuter, Greig. 2014. Beyond the Model Worker: Surveying a Creative Precariat. Culture Unbound 6 (1): 263-284.

de Peuter, Greig, Nicole Cohen and Enda Brophy. 2012. Interns Unite! (You Have Nothing to LoseLiterally). Briarpatch Nov/Dec: 8-12.

Deuze, Mark. 2007. Media Work. Cambridge, MA: Polity Press.

Flint, Joe. 2014. Reality TV Production Deal Prices Escalate Amid Consolidation Wave. LA Times, June 3. Accessed December 1, 2014. http://www.latimes.com/entertainment/envelope/cotown/la-fi-ctunscripted-consolidation-20140603-story.html\#page=1.

Fuchs, Christian. 2014. Digital Labor and Karl Marx. New York: Routledge.

Hall, Stuart. 1996. Introduction: Who Needs Identity? In Questions of Cultural Identity, edited by Stuart Hall and Paul du Gay, 1-17. London: Sage.

Hearn, Alison. 2008. Variations on the Branded 'Self': Theme, Invention, Improvisation and Inventory. In The Media and Social Theory, edited by David Hesmondhalgh and Jason Toynbee, 194-210. New York: Routledge.

Hearn, Alison. 2010. Reality Television, The Hills, and the Limits of the Immaterial Labor Thesis. tripleC 8 (1): 60-76.

Hearn, Alison. 2014. Producing 'Reality': Branded Content, Branded Selves, Precarious Futures. In $A$ Companion to Reality Television, edited by Laurie Ouellette, 437-454. Malden, MA: Wiley-Blackwell.

Heckman, James. 2012. Hard Evidence on Soft Skills. Accessed December 1, 2014. http://www.irp.wisc.edu/publications/focus/pdfs/foc292b.pdf.

Hesmondhalgh, David. 2010. User-generated content, free labor and the cultural industries. Ephemera: theory \& politics in organization 10 (3/4): 267-284.

Huws, Ursula. 2007. The Creative Spark in the Engine: Special Issue of Work, Organization, Labor \& Globalization (1): 1-12.

Huws, Ursula. 2010. Expression and expropriation: the dialectics of autonomy and control in creative labor. ephemera: theory \& politics in organization 10 (3/4): 504-521.

Kelley, Tiffany. 2006. Reality Show Participants: Employees or Independent Contractors? Employee Relations Law Journal 32 (1): 15-38.

Marx, Karl. 1990. Capital: A Critique of Political Economy, Vol. 1. New York: Penguin Press.

Mayer, Vickie. 2011. Below the Line: Producers and Production Studies in the New Television Economy. Durham and London: Duke University Press.

Mirrlees, Tanner. 2013. Global Entertainment Media: Between Cultural Imperialism and Cultural Globalization. New York: Routledge.

Mooers, Colin. 2014. Imperial Subjects: Citizenship in an Age of Crisis and Empire. New York: Bloomsbury Academic.

Mosco, Vincent. 2009. The Political Economy of Communication. Thousand Oaks, CA: Sage.

Mosco, Vincent and Catherine McKercher. 2008. The Laboring of Communication: Will Knowledge Workers of the World Unite? Lanham, MD: Lexington Books.

Nieves, Racquel. 2014. The Future of Unpaid Internships in the Entertainment Industry. Accessed December 1, 2015. http://dlreporter.com/2014/06/25/future-of-unpaid-internships-in-entertainmentindustryl.

Oullette, Laurie and James Hay. 2008. Better Living Through Reality TV. Malden, MA: Blackwell.

Perlin, Ross. 2012. Intern Nation: How to Earn Nothing and Earn Little in the Brave New Economy. New York: Verso.

Raphael, Chad. 1997. The Political Economic Origins of Reali-TV. Jump Cut 41 (2): 102-109.

Ross, Andrew. 2004. No-Collar: The Humane Workplace and its Hidden Consequences. Philadelphia, PA: Temple University Press. 
Ross, Andrew. 2009. Nice Work If You Can Get It: Life and Labor in Precarious Times. New York and London: New York University Press.

Ross, Andrew. 2013. In Search of the Lost Paycheck. In Digital Labor: The Internet as Playground and Factory, edited by Trebor Scholz, 13-32. New York: Routledge.

Ross, Andrew. 2014. Reality Television and the Political Economy of Amateurism. In A Companion to Reality Television, edited by Laurie Ouellette, 29-39. Malden, MA: Wiley-Blackwell.

Scholz, Trebor, ed. Digital Labor: The Internet as Playground and Factory. New York: Routledge.

Sterne, Peter. 2014. Firm puts Vice in its sights for intern class action. Accessed December 1, 2014. http://www.capitalnewyork.com/article/media/2014/06/8546612/firm-puts-vice-its-sights-intern-classaction.

Slocum, Charles. B. 2014. The Real History of Reality TV: Or, How Allen Funt Won the Cold War. Accessed December 1, 2014. http://www.wga.org/organizesub.aspx?id=1099.

Terranova, Tiziana. 2004. Network culture: Politics for the information age. London: Pluto Press.

Yamada, David. 2013a. Unpaid intern cannot bring sexual harassment claim under NYC human rights law, judge rules. Minding the Workplace. Accessed December 1, 2014.

https://newworkplace.wordpress.com/2013/10/05/unpaid-intern-cannot-bring-sexual-harassmentclaim-under-nyc-human-rights-law-judge-rules/.

Yamada, David. 2013b. The Legal and Social Movement Against Unpaid Internships. Legal Studies Research Paper Series 13-34: 1-27.

Waxman, Sharon. 2005. Union Plans to File Suit for Reality TV Workers. New York Times, June 29. Accessed December 1, 2014. http://www.nytimes.com/2005/06/29/arts/television/29real.html?pagewanted=all\& $r=0$.

\section{About the Author}

Tanner Mirrlees

Tanner Mirrlees is an Assistant Professor in the Communication and Digital Media Studies Program at the University of Ontario Institute of Technology. His research centers on key topics in the political economy of communications tradition such as US empire and communications, the military-industrialcommunications-media complex, and the politics and ideology of popular culture. He is the author of Hearts and Mines: The US Empire's Culture Industry (University of British Columbia Press 2015) and Global Entertainment Media: Between Cultural Imperialism and Cultural Globalization (Routledge 2013), and articles in journals such as Alternate Routes, Cineaction, Democratic Communiqué, Global Media Journal, The International Journal of Media and Cultural Politics, and The Journal for Critical Education Policy Studies. 